\title{
THE IMPACTS OF TRADE LIBERALIZATION ON POVERTY REDUCTION IN INDONESIA
}

\author{
Mufti Alam Adha1, Faiza Husnayeni Nahar², Muhammad Azizurrohman ${ }^{3}$ \\ ${ }^{1}$ Faculty of Islamic Studies, Universitas Ahmad Dahlan, Indonesia \\ Jl. Kapas 9, Semaki, Umbulharjo, Yogyakarta 55166 \\ ${ }^{2}$ Faculty of Economics and Business, Universitas Muhammadiyah Yogyakarta, Indonesia \\ Jl. Brawijaya, Geblagan, Tamantirto, Kasihan, Bantul, Daerah Istimewa Yogyakarta 55183 \\ ${ }^{3}$ Faculty of Management, National Chiayi University, Taiwan \\ No.300 Syuefu Rd., Chiayi City 60004, Taiwan \\ Correspondence E-mail: faizahusnayeni@umy.ac.id \\ Received: August 2018; Accepted: October 2018
}

\begin{abstract}
Nowadays, trade liberalization is considered as development strategy policy to increase economic growth and reduce poverty in many countries, particularly in developing countries. It is reported that Indonesia has been actively joining many trade agreements in order to ease the distribution of goods and services to other countries. Hence, this study analyses the impact of trade liberalization on poverty reduction by using an Ordinary Least Square (OLS) method from 1984 to 2017. The Trade Openness Ratio (TOR) is used as a dependent variable in order to measure trade liberalization. Other variables such as GDP, exchange rate and labor force are considered as control variables. The empirical result shows that TOR and labor force have a positive impact on poverty, whereas GDP and exchange rate have a negative impact. This finding is different with previous researches, particularly where trade liberalization has been negatively affecting poverty. Such a result is justifiable because Indonesian firms are not ready to compete with foreign firms where high competitiveness exist.

Keywords: Trade Liberalization; Indonesia; GDP; Exchange Rate; Labor Force

JEL Classification: F10, F19, F47
\end{abstract}

\section{INTRODUCTION}

In this globalization era, trade liberalization compromises lots of benefits to many countries, especially for the developing ones. It is reported that the number of exported products, particularly in manufacturing goods, has increased rapidly over the last 30 years (Levin and Ohlin, 2008). Most parts of Asia and Africa continents (Cockburn, Decaluwé, and Robichaud, 2006) experience the gains of trade liberalization, including an increase on welfare society and reduction in poverty level (Hayashikawa, 2009). Ghana (Bhasin and Annim, 2005), Philippines, Nepal, India, Pakistan (Cockburn, Decaluwe, and Robichaud, 2008), and Indonesia (Kis-Katos and Sparrow, 2013) exemplify the countries that experience the benefit of trade liberalization in these recent decades.

Indonesia joined General Agreement of Tariff and Trade (GATT) since 1950. It was the first agreement that Indonesia was involved. Then, it was followed by many other trade agreements among nations. By joining trade liberalization, Indonesia changes the orientation of trade policy from inward looking to outward looking. Even though Indonesia believes that international trade will improve economic welfare, yet the government should be aware of the consequences of implementing this policy. Hence, by increasing specialization goods by reducing transportation cost, Indonesia can sustain their economic growth for a long-term period (Levin and Ohlin, 2008).

Openness to trade is an important element of economic policy to achieve the sustainability 
of economic growth and trade liberalization is the way to achieve it (McCulloch, Winters, and Cirera, 2001). By opening up the access to the global economies, such as reducing tariff and nontariff barrier on international trade, Indonesia can develop more partnership or diplomatic relationship with many countries over the world. When Indonesia can produce specialization products, it might increase the production efficiently which results on the increasing demands and firm will need to hire more labors. Recruiting more labors will indirectly affect the household's income. Afterward, the economy will grow up faster and poverty alleviation can be undertaken.

On the other hand, although trade liberalization gives positive multiplier effects on the economy, it might also harm particular party since it leaves some people behind in poverty (Winters, McCulloch, and McKay, 2004). Many unskilled workers cannot compete to the highskilled ones, the small firm will be in problem due to big firm's higher power to export goods in larger scale (Winters, 2000), local goods cannot compete against imported goods since overseas brands have better quality with lower price as well (Harrison, 2007; Eaton and Grossman, 1986).

This paper result is expected to uncover the impact of trade liberalization on poverty reduction. In addition, it will give a recommendation for policymakers to solve the consequences of implementing this trade liberalization policy. Therefore, the Indonesian government needs to evaluate the trade liberalization policy effectively and efficiently in order to pursue sustained economic growth and reducing poverty level (Feridhanusetyawan and Pangestu, 2003).

Various literature about trade liberalization and poverty has been pursued by many researchers in over the last two decades. According to Cockburn, Decaluwe, and Robichaud (2008), trade liberalization might affect poverty through consumption and income effects. Due to the declining transport cost (removal barrier tariff and non-tariff), firms can export specialization goods in large number to overseas and they need to hire more labors to reproduce more products efficiently. Expanding business, increasing labor demand, and increasing income will indirectly reduce the number of unemployment. Hence, many people can fulfill their basic needs and households can consume more goods at lower prices. In addition, since open trade allows export and import among nations a high surplus of goods will affect a price-reduction. This lower cost will give benefit to the country. In the end, combining income and consumption effect will reduce poverty.

Winters (2000) described the labor market theory to explain the relationship between international trade and poverty in developing countries. If open trade allows the country to export more labor-intensive goods and replace the local production of capital and skillintensive goods through import, it will increase the labor demand, especially the informal sector. If poverty is becoming the main target of some countries, hence, increasing the demand for labor will help to reduce in the long term.

Banerjee and Newman (2004), as cited by Topalova (2007), explained that HeckscherOhlin model predicts that gains to trade should flow to an abundant factor, which suggests that unskilled labors in developing countries might get benefit from globalization. However, according to the new theories, the effect of trade liberalization is constantly different to the standard economic theory which states that openness to trade might reduce the wage of unskilled labors even in a labor-abundant country. Hence, the gap between the rich and the poor keeps widening.

Winters (2000) explained the impact of trade liberalization on poverty in African countries by using grass-roots perspective and interviews from secondary sources to identify the different ways how poor people in Zimbabwe and Zambia have been affected. Openness and trade liberalization are important 
components of policy development since with that element, economic growth might increase due to high poverty reduction. Trade liberalization increases the economic opportunities for consumers and producers and to raise earning for workers. However, it is impossible to pretend that trade liberalization never pushes anyone into poverty, nor even that liberalization cannot increase the depth of poverty in a certain condition. Hence, it is important to manage liberalization by looking at the country's condition in order to play a positive role regarding poverty reduction.

This paper gives several suggestions. The first, unpredicted poverty possibly rises from market failure. In the case of Zambia, many farmers found difficulties to plant their maize due to the lack of skill and lost of seeds. It cannot be denied that the poor cannot take all of the advantages of trade liberalization since they have less skill compared to labors in a big firm who are very well-skilled. The second, market segmentation seems to prevent the benefits of liberalization from optimally spreading. The third one is related to the uneven effect of liberalization on households. For example, there happens a high demand for clothing export in Southeast Asia while there is less demand for a manufacturing job in Africa. Considering this contrast, policymakers should prepare for the worst when they choose to implement trade liberalization. Being capable to manage the consequences is very important after applying trade liberalization.

Furthermore, Topalova (2007) shows the impact of trade liberalization on poverty and inequality using a case in Indian district. Since India represents one-third of the world's poor population, this research really needs to be more analyzed. To determine whether there is a relationship between liberalization and changes in poverty and inequality, this paper uses variations in its timing, degree of liberalization across industries, and locations of industries in Indian districts. The data for this paper were obtained from three sources, which are household survey data, Indian National Sample Survey (NSS), and various other households and individual characteristics. The surveys cover 75,000 rural and 45,000 urban households. Besides, this paper examines whether poverty and inequality in those districts are related to the specific district's trade policy shock. The paper found that trade liberalization increases the poverty rate and gap in the rural district which industries are more exposed to liberalization. It is interesting to note that the effect of trade liberalization did not affect India in general but only specific to areas with more or less exposure to liberalization. The fact that these effects were not evenly spread in one country becomes an issue in the implementation of trade liberalization. The evolution of tariff barrier could be the cause of this inequality problem. Besides, the industries affected by tariff reduction would give slow progress in poverty reduction. So to say, the areas where trade liberalization is concentrated experiences slow poverty reduction.

Afterward, research from Winters et al. (2004) explained the evidence of trade liberalization effect on poverty by reviewing previous literature. This paper found that trade liberalization can reduce poverty in the long run. However, the impact of trade liberalization on poverty depends on the environment in which it is carried out, such as the policies in those areas. The fact that the poor have less ability than the richer to protect themselves to take advantages of trade liberalization opportunities might become an issue that the government has to handle. In the end, even though trade liberalization may not be the most powerful act to reduce poverty, it is one of the easiest to change. By reducing the tariff and nontariff barrier, the more resources will be saved. Hence, trade liberalization becomes one of the most cost-effective anti-poverty policies that are easy to do for government and it can become an important component of "pro-poor" attempts to improve the development strategy in alleviating poverty. 
In short, that literature review proposes some points in common. The majority of those study state that trade liberalization has a significant contribution, yet there is still an issue on its implementation. It is possible and understandable that different methods and different data set yield different outcomes such as that trade liberalization can reduce poverty in areas with more or less exposure to liberalization, but not in a country as a whole.

\section{RESEARCH METHOD}

This section aims to measure how much impact of remittance is on poverty. To answer the question, an empirical study is pursued by using time series data including poverty, trade openness ratio, exchange rate, and labor force participation in Indonesia. The data of those variables were collected from the World Bank and Statistic Indonesia, starting from 1984 to 2017. The total observation is 33 years. In this study, the econometric model to be estimated is as follows:

$$
P V=c-a_{1} T O R_{i}-a_{2} E X C_{i}-a_{3} L F-a_{4} G D P+\varepsilon
$$

Where $\mathrm{PV}$ is poverty, $\mathrm{c}$ is constant, TOR is traded openness ratio; EXC is exchange rate, LF is the labor participation rate, GDP is the income and $\varepsilon$ is error term.

\section{Trade Openness Ratio}

To measures the trade openness ratio, the indicator is defined as follows:

\section{Trade Ratio $=($ Export + Imports $) / G D P$}

Trade openness is expected to negatively affect poverty. If the amount of trade openness ratio is high, the level of poverty will be low. The connection between trade openness and poverty reduction is actually through economic growth. Trade, both import and export, is vital to any successful modern economy since trade openness is the most important influence on economic growth (David, 2007). If trade openness is increased, economic growth will increase as well and the poverty level will decline due to household income increment. It means that this trade openness ratio variable is expected to have a negative sign (-) to poverty. Thus, the higher the level of trade openness ratio, the lower the level of poverty will be.

\section{Exchange Rate}

The exchange rate is expected to negatively affect poverty. The exchange rate will change whenever the currency value is changing. When the currency is high, many consumers will be more willing to consume since their purchasing power is increasing, thus reducing poverty level. So, the exchange rate is expected to have a negative sign (-). The higher the level of exchange rate, the lower the level of poverty will be.

\section{Labor Force Participation}

Labor force participation is expected to negatively affect poverty. When trade liberalization is undertaken in a country, many big firms are able to expand their business by exporting their goods to other countries. Many firms will hire more labors in order to fulfill the high demand for goods. Even though the price of export is reduced because of the high demand, the profit they earn is greater than before. By hiring more labors, the amount of household income will increase, leading to a reduction in poverty as well. Hence, this labor force participation variable is expected to have a negative sign (-) to poverty. The higher the level of labor force participation, the lower the level of poverty will be.

\section{GDP}

GDP might negatively influence poverty because the more GDP received by Indonesia, the lower the number of poverty level achieved is. Increase in GDP might influence poverty indirectly since high GDP is associated with the increasing income growth of the poor people (Romer and Gugerty, 1997). The household can 
fulfill their basic need and they can upgrade their preferences on consuming good as long as their income is increasing as well. Hence, GDP variable is expected to have a negative sign (-) to poverty. The higher the level of GDP, the lower the level of poverty will be.

All variables in this model are in percentage except labor force and GDP that need to be transformed into a log of Trade Openness Ratio, Labour Force, GDP, and Exchange Rate are expected to have negative effects, the expected signs are negatives. The dependent variable is the poverty level while the independent variables are the trade openness ratio, exchange rate, labor force, and GDP.

Since the data is a time series, the stationary needs to be confirmed first. If all variables have been completely stationary, the OLS method can be used afterward. Under certain assumptions, the method of least squares has some very attractive statistical properties that have been made as one of the most powerful and popular methods in regression analysis (Gujarati, 2004).

\section{RESULT AND DISCUSSION}

It is found that all variables are stationary and fulfill the criteria of classical assumption test as seen on table 1, 2, and 3. On the first table, it can be seen that the p-value of Obs*RSquared is 0.0618 which is larger compared to the level of significance (0.05). It can be concluded that there is no autocorrelation problem. Afterward, on the second table, it is proven that there is no heteroskedasticity problem, by considering that the level of significance is $0.01(0.0106>0.01)$. Afterward, in table 3 , it is found that there is no problem of multicollinearity. In this case, the multicollinearity test used VIF test by scoring each auxiliary regression. If each variable is lesser than 10, it means that it passes the requirement of VIF test. After preceding the regression, the OLS result can be seen in table 4 .
The empirical result of this model shows that all variables are statistically significant to the level of significance.

Table 1. Autocorrelation Test for OLS

\section{Estat bgodfrey}

Breusch-Godfrey LM test for autocorrelation

\begin{tabular}{llll} 
Lags (p) & Chi2 & $\mathrm{df}$ & Prob $>$ chi2 \\
1 & 3.488 & 1 & 0.0618 \\
\hline \multicolumn{4}{c}{ H0: no serial correlation }
\end{tabular}

Source: Author estimation (2018)

Table 2. Heteroskedasticity Test for OLS

\section{Breusch-Pagan / Cook-Weisberg test for \\ heteroskedasticity \\ H0: Constant variance}

Variables: fitted values of poverty

\begin{tabular}{ll} 
Chi2 $(1)$ & $=6.54$ \\
Prob $>$ chi2 & $=0.0106$ \\
\hline Source: Author estimation & $(2018)$
\end{tabular}

Source: Author estimation (2018)

Table 3. Multicollinearity test for OLS

\begin{tabular}{ccc}
\hline Variable & VIF & 1/VIF \\
\hline lgdp & & \\
D1. & 9.54 & 0.104808 \\
exchange & & \\
D1. & 8.86 & 0.112812 \\
tor & 2.40 & 0.416846 \\
llabor & & \\
D1. & 1.67 & 0.599004 \\
Mean VIF & 5.62 & \\
\hline
\end{tabular}

Source: Author estimation (2018)

TOR has a positive sign and the estimation suggests that $1 \%$ change in trade openness ratio leads to an increase of poverty by $7.15 \%$. Afterward, according to the estimation, 1\% change in the first difference of variables GDP, EXCH will reduce poverty by 0.467 and $0.006 \%$ respectively. Meanwhile, $1 \%$ change in the first difference of LF will increase poverty by $1.93 \%$.

Trade openness ratio is expected to have a negative sign, but it does not. This study found that trade openness ratio probably increases poverty in Indonesia. The justification reason can be explained through some possible answers. 
Table 4. Estimation Results of Regression Analysis

(Dependent Variable is Poverty level)

\begin{tabular}{cccc}
\hline Variables & Coefficient & T Statistic & Prob. \\
\hline C & 13.34749 & 3.69 & 0.001 \\
TOR & 7.151135 & 1.97 & $0.059^{* * *}$ \\
D (LNGDP) & -0.4670141 & -3.39 & $0.002^{* *}$ \\
D (EXCH) & -0.006245 & -3.52 & $0.001^{* *}$ \\
D $(\mathrm{LF})$ & 1.938998 & 1.84 & $0.076^{* * *}$ \\
\hline
\end{tabular}

* denotes significance at $1 \%$ level

** and *** indicate significant at 5\% level and 10\% level respectively

$\mathrm{R}^{2}=0.5744 \overline{\mathrm{R}^{2}}=0.5136$ F-stat $=9.45 ;(\mathrm{P}$-value $=0.0001)$

Source: Author estimation (2018), data obtained from year 1984-2017

First, Indonesian firms have not been ready yet to compete with overseas products. Even though the barrier among nations such as taxreduction has been removed, the qualities between imported and local products are still significantly different. For more than decades, the number of imported product stores has increased gradually. It is reported that the total imported goods and services coming to Indonesia was about 68 billion in 2000 and then increased rapidly to 200 billion \$US in 2017.

Afterward, since Indonesia welcomes trade openness, it might expose many foreign firms to compete with Indonesian products which resulting in tight competition between imported and local products (Goffa and Singh, 2014). As local firms have limited capital, they tried an alternative way to reduce the cost by hiring more temporary labors. They even fire some of their workers to recover losses. Hence, the increase in trade openness might lead to an increase in the number of informal sectors. The lesser income that household received will make them suffer more. They cannot fulfill their basic need which in the end, poverty alleviation cannot be undertaken.

In addition, according to Winters, McCulloch, and McKay (2004), trade openness might decline the welfare of some people, particularly the one who is limited in skills. The high competitiveness among firms, either the local or foreign ones, will definitely require them to hire labors which can help to produce goods and services on a larger scale. The one who does not have skills will lose to those with good skills. Most of the firms need workers who are capable to use technology or at least having basic skills, such as able to use Microsoft word and excel in the computer, able to speak English, and so forth. Hence, increasing trade openness ratio might result in the increasing number of poor people in the long term.

It is such a dilemma when Indonesia needs to open their gate to join the global economy in order to increase their economic growth and reduce poverty, yet they experience a counter effect. Poverty is not an easy problem for Indonesia that can be solved in a short period. It even becomes the problem of worldwide.

On the other hand, Cockburn, Decaluwe, and Robichaud (2008) explained that trade liberalization has a positive impact on welfare and poverty although the number is small. It is reported that urban households will gain more in terms of welfare and poverty compared to the rural ones. Many firms are established in the urban area, hence, the poor remain poor if they still live in a rural area. In addition, rural people are lacking in skill and knowledge compare to urban people. So in term of human capital, they are not capable enough to face the trade liberalization which is full of skilled people. 
The next variable is GDP. It is found that GDP has a negative sign which results on giving a good impact on poverty reduction. The higher GDP received by Indonesia, the higher the number of poorer reduced in the future. An increase in GDP is related to the stable economic growth of Indonesia (Nahar, Adha, and Muhammad Azizurrohman, 2018). Snyder and Chern (2008) stated that an increase in income leads the household to change their preferences and lifestyle. The more money they earn, the more economic status will be changed. At first, they can only fulfill the basic needs; afterward, they can use the money from the increased income for non-basic needs.

Exchange rate shows a negative sign, which means that every $1 \%$ change in exchange rate reduces poverty by $0.006 \%$. According to Nahar and Arshad (2017), exchange rate indirectly reduces poverty. When the exchange rate increases, for instance, 1 US Dollar is becoming IDR 12,000 from IDR 15,000; the import seller will get benefit by buying import product with lower price. Even though the benefit of trade liberalization might happen to particular parties, it will still help the government to boost up the economic growth and poverty reduction.

Moreover, the labor force has a positive sign. The estimation suggests that every $1 \%$ change in labor force increases poverty by $1.9 \%$. In researcher's point of view, the possible reason is related to the previous explanation. When trade liberalization bridges more foreign firms, local firms have to compete with them. As the results, the local firms need to reduce some cost by laying off the workers. If the workers can be paid lower, the local firm will not have to lay them off. That kind of condition pushes them into the informal sector, which results on the increasing number of the poorer in Indonesia.

\section{CONCLUSION}

From this result, it is found that all variables are significant and influence the poverty level. Even though the main variable, which is trade liberalization on trade openness ratio proxy, shows contradicting result from the initial hypothesis, the overall results still indicate that trade liberalization policy should be evaluated. If Indonesia is $100 \%$ ready to face the globalization economy, the future results might be different. To be ready, the governments need to take several measures, such as training the workers in every region. The training should include basic standard skills, such as good at technology, decent manner, proficient in more than 3 languages, and so forth. The empirical result shows that TOR and labour force have a positive impact on poverty, whereas GDP and exchange rate have a negative impact. This finding is different with previous researches, particularly where trade liberalization has been negatively affecting poverty. Such a result is justifiable because Indonesian firms are not ready to compete with foreign firms where high competitiveness exist.

\section{REFERENCES}

Bhasin, V.K, and Annim, S. K. (2005). Impact of Elimination of Trade Taxes on Poverty and Income Distribution in Ghana. Global Development Network.

Cockburn, J., Decaluwé, B., and Robichaud, V. (2006). Trade liberalization and poverty: Lessons from Asia and Africa. Poverty and Economic Policy, Micro Impact of Macro and Adjustment Policies (MIMAP) Project, (April).

Cockburn, J., Decaluwe, B., and Robichaud, V. (2008). Trade Liberalization and Poverty: A CGE Analysis of the 1990s Experience in Africa and Asia. Poverty and Economic Policy (PEP) Research Network.

David, H.L. (2007). A Guide to Measures of Trade Openness and Policy. Retrieved February 22, 2013.

Eaton, J. and Grossman, G.M. (1986). Optimal 
trade and industrial policy under oligopoly. The Quarterly Journal of Economics, 101(2), 383-406.

Feridhanusetyawan, T., and Pangestu, M. (2003). Indonesian Trade Liberalization: Estimating The Gains. Journal-Bulletin of Indonesian Economic Studies, 39(1), 1-33.

Goffa, M.L., and Singh, R.J. (2014). Does Trade Reduce Poverty? A View from Africa. Journal of African Trade, 1(1), 5-14.

Gujarati. (2004). Based Econometric, $4^{\text {th }}$ Ed. New York: McGraw-Hill Companies.

Harrison, A. (2007). Trade liberalization, poverty and inequality: Evidence from Indian districts. Chicago: University of Chicago Press. Available from https://www.nber.org/books/harr016. (Accessed: $1^{\text {st }}$, August 2018).

Hayashikawa, M. (2009). Trading Out of Poverty: How to Aid for Trade can Help. OECD Journal on Development, 10(2), 1-38.

Kis-Katos, K., and Sparrow, R. (2013). Poverty, Labour Markets and Trade Liberalization in Indonesia. The Institute for the Study of Labor Discussion Paper, 7645 , 1-32. https://doi.org/10.1016/j.jdeveco.2015. 07.005

Levin, J., and Ohlin, M. (2008). Trade Policies and Export Growth: Employment and Poverty Impact in Tanzania. SIDA, Swedish International Development Cooperation Agency, Oct 2008.

McCulloch, N., Winters, L.A., and Cirera, X. (2001). Trade Liberalization and Poverty: A Handbook. Centre for Economic Policy Research. London, UK: DFID Department for International Development.

Nahar, F.H., Adha, M.A., and Azizurrohman, M. (2018). Effects of Remittances on Economic Growth in Indonesia. In 9th International Conference on Socio-economic and Environmental Issues in Development, 1, 11-20.

Nahar, F. H., and Arshad, M.N.M. (2017). Effects of Remittances on Poverty Reduction: The Case of Indonesia. Journal of Indonesian Economy and Business, 32(3), 163-177.

Romer, M. and Gugerty, M. (1997). Do Economic Growth Reduce Poverty? Technical Paper, 1-33.

Snyder, S., and Chern, W.S. (2008). The Impact of Remittance Income on Rural Households in China. Journal of SocioEconomics, 1(1), 38-57.

Topalova, P. (2007). 'Trade liberalization, poverty and inequality: Evidence from Indian districts' in A Harrison, (ed), Globalization and poverty 1-46. Chicago: University of Chicago Press. Available from

https://www.nber.org/chapters/c0110 .pdf. (Accessed: $1^{\text {st }}$ August 2018)

Winters, L.A. (2000). Trade Liberalisation and Poverty. DFID, 1-42.

Winters, L.A., McCulloch, N., and McKay, A. (2004). Trade Liberalization and Poverty: The Evidence So Far. Journal of Economic Literature, 42(1), 72-115. 